\title{
1 COVID-19 and HIV co-infection: a living systematic evidence map of
}

\section{2 current research}

$4 \quad$ Gwinyai Masukume ${ }^{1 *}$, Witness Mapanga ${ }^{2}$, Doreen $\mathrm{S}$ van $\mathrm{Zyl}^{3}$

5

$6 \quad{ }^{1}$ Division of Epidemiology and Biostatistics, University of the Witwatersrand, School of

7 Public Health, Johannesburg, South Africa

$8{ }^{2}$ Non-Communicable Diseases Research (NCDR) Division of the Wits Health Consortium,

9 Faculty of Health Sciences, University of the Witwatersrand, Johannesburg, South Africa

$10 \quad{ }^{3}$ Private practitioner, Johannesburg, South Africa

12 Correspondence

* parturitions@gmail.com 
medRxiv preprint doi: https://doi.org/10.1101/2020.06.04.20122606; this version posted June 7,2020 . The copyright holder for this preprint (which was not certified by peer review) is the author/funder, who has granted medRxiv a license to display the preprint in perpetuity.

It is made available under a CC-BY 4.0 International license .

\section{Abstract}

22 The world currently faces two ongoing devastating pandemics. These are the new severe acute respiratory syndrome coronavirus 2/coronavirus disease 2019 (SARS-CoV-2/COVID19) and the prior human immunodeficiency virus/acquired immune deficiency syndrome (HIV/AIDS) pandemics. The literature regarding the confluence of these global plagues expands at pace. A systematic search of the literature considering COVID-19 and HIV coinfection was performed.

After five months, from the beginning of the COVID-19 pandemic, there were at least thirtyfive studies reported from thirteen countries. These ranged from individual case reports and series to cohort studies. Based on studies that could be extrapolated to the general population, co-infected individuals with suppressed HIV viral loads did not have disproportionate COVID-19 sickness and death. At least four patients, newly diagnosed with HIV recovered from COVID-19. Current evidence suggests that co-infected patients should be treated like the general population.

This ongoing living systematic evidence map of contemporary primary SARS-CoV-2 and HIV co-infection research provides a platform for researchers, policy makers, clinicians and others to more quickly discover and build relevant insights.

\section{Key words}

SARS-CoV-2; COVID-19, HIV, AIDS, Co-infection, Coronavirus, 
medRxiv preprint doi: https://doi.org/10.1101/2020.06.04.20122606; this version posted June 7, 2020. The copyright holder for this preprint (which was not certified by peer review) is the author/funder, who has granted medRxiv a license to display the preprint in perpetuity.

It is made available under a CC-BY 4.0 International license .

44

45

46

47

\section{Introduction}

The confluence of the ongoing new severe acute respiratory syndrome coronavirus 2/coronavirus disease 2019 (SARS-CoV-2/COVID-19) and prior human immunodeficiency virus/acquired immune deficiency syndrome (HIV/AIDS) pandemics presents profound challenges for public health.[1, 2] On 31 December 2019, a pneumonia cluster of unknown cause was reported to the World Health Organization.[3] This report foreshadowed the emergence of a new pandemic. Due to the emergence of the COVID-19 pandemic, scientific research has been growing very fast.[4] We thus sought to provide an updated systematic curation and key insights from literature on co-infection with the pandemic viruses.

\section{Methods}

Two independent reviewers (GM and WM) searched the following databases: PubMed (via the PubMed/MEDLINE interface), the Scientific Electronic Library Online, Scopus (via the EBSCO interface), African Journals OnLine, and the pre-print server MedRxiv (using key words).

The Boolean search approach, for 2020 literature, (COVID* OR SARS-CoV-2 OR severe acute respiratory syndrome OR coronavirus OR corona virus) AND (HIV OR AIDS OR human immunodeficiency virus), was used for each database (PubMed search strategy). The last online database searches were on 3rd June 2020. Searches were supplemented by a hand search of references and by use of the 'cited by' feature of Google Scholar. Inclusion criteria included primary studies reporting individuals with co-infection. Exclusion criteria included editorials, commentaries and reviews.

All records that were identified from the searches were collated into EndNote software.

Duplicates were removed. The screening of titles, abstracts and full-texts were performed, 
medRxiv preprint doi: https://doi.org/10.1101/2020.06.04.20122606; this version posted June 7, 2020. The copyright holder for this preprint (which was not certified by peer review) is the author/funder, who has granted medRxiv a license to display the preprint in perpetuity.

It is made available under a CC-BY 4.0 International license .

guided by the criteria described earlier. An HIV clinician (DSvZ) acted as the third reviewer and provided domain specific insights.

\section{$71 \quad$ Results}

72 Presented in order of the first published paper from a country, there were thirty five papers

73 from thirteen countries: China,[5-11] Spain,[12-14] Italy,[15, 16] United States,[17-29]

74 United Kingdom,[30, 31] Turkey,[32] Germany,[33] South Africa,[34] Singapore,[35]

75 Uganda,[36], Cyprus,[37] (Figure 1), Japan,[38] and Austria.[39] The first known case of

76 COVID-19 and HIV co-infection was reported from China on 11 March 2020.[5] From then

77 onwards, the number of reports has increased quickly (Figure 2). Please see the

78 supplementary appendix for further details and summaries of the papers. 

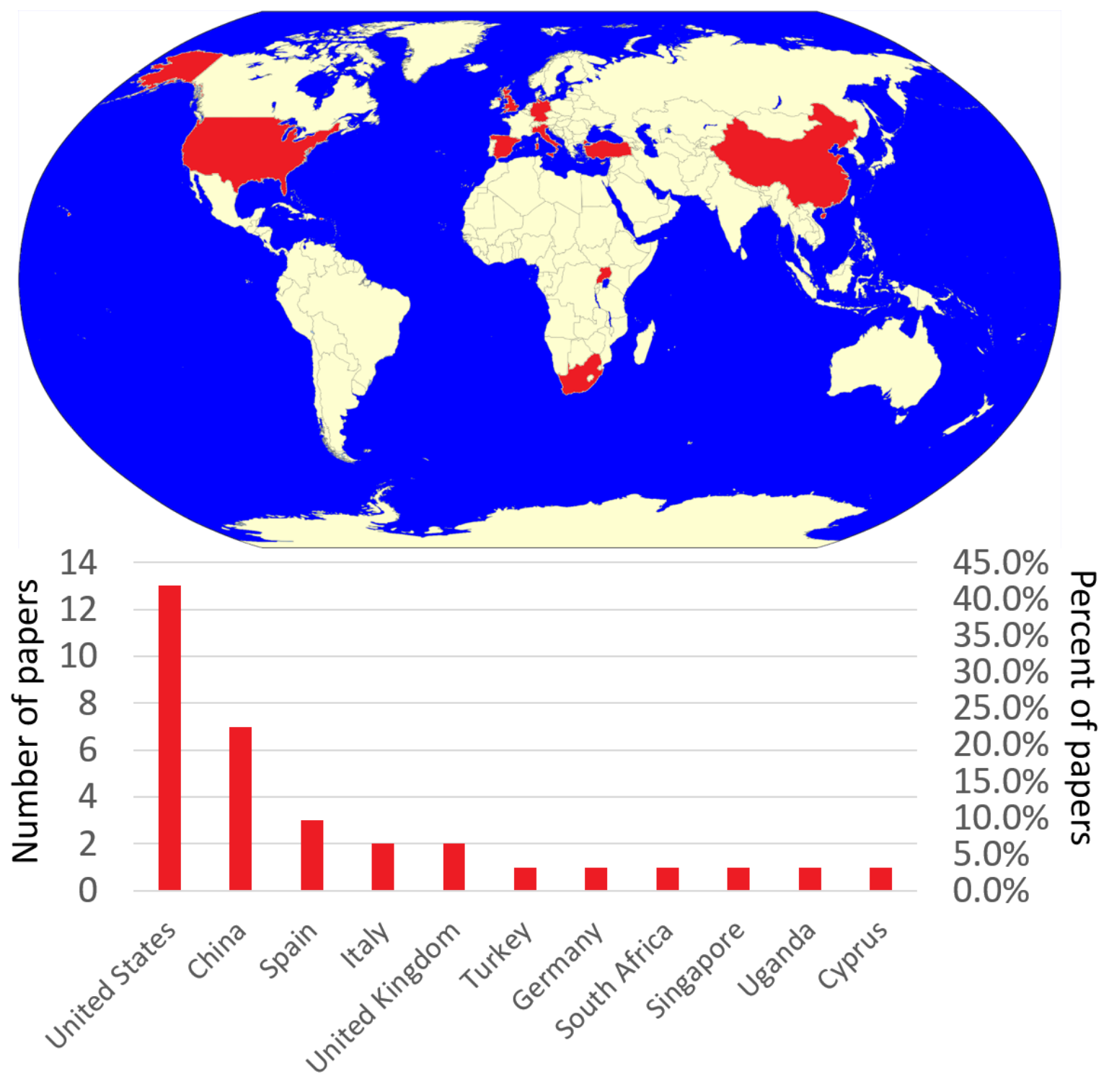

81 Figure 1. Countries reporting severe acute respiratory syndrome coronavirus 2 (SARS-CoV-

2) and human immunodeficiency virus (HIV) co-infection up to 31 May 2020. 
medRxiv preprint doi: https://doi.org/10.1101/2020.06.04.20122606; this version posted June 7, 2020. The copyright holder for this preprint (which was not certified by peer review) is the author/funder, who has granted medRxiv a license to display the preprint in perpetuity.

It is made available under a CC-BY 4.0 International license .

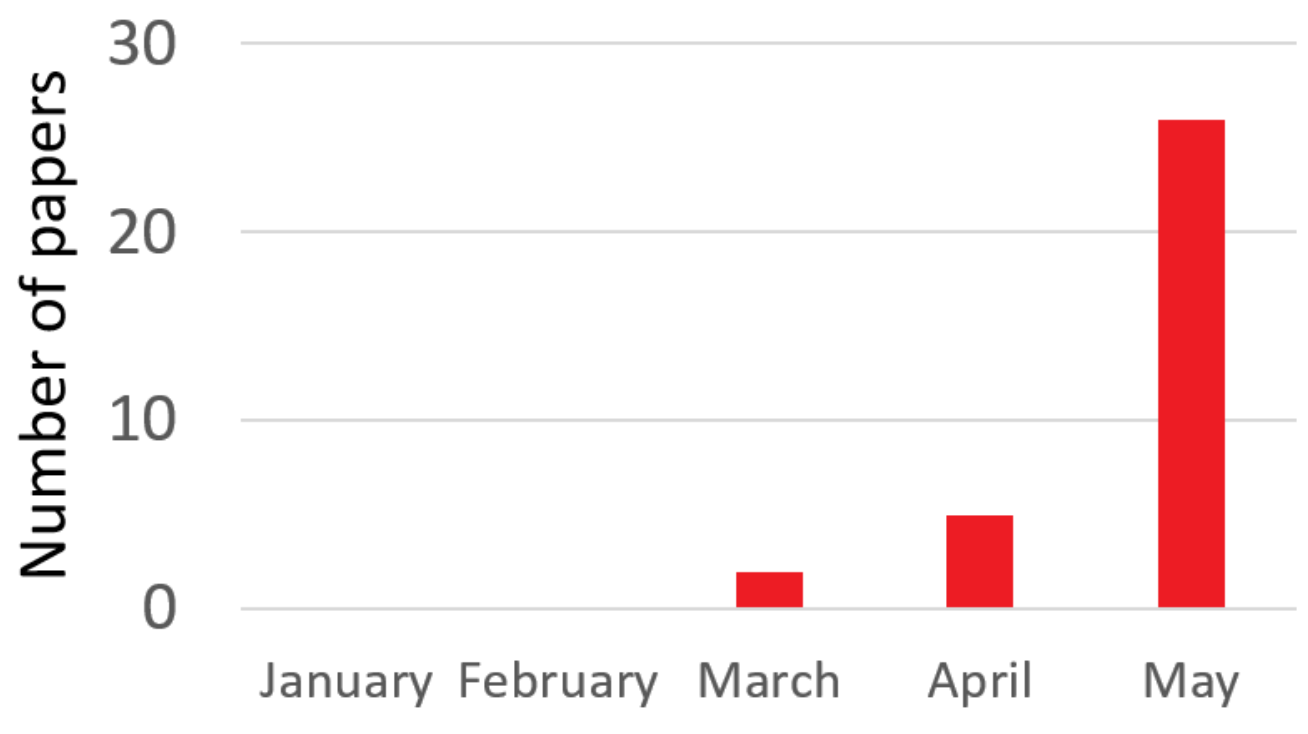

Figure 2. Monthly number of papers reporting severe acute respiratory syndrome coronavirus

2 (SARS-CoV-2) and human immunodeficiency virus (HIV) co-infection up to 31 May 2020.

Common symptoms included cough, fever, shortness of breath and fatigue. Loss of the sense of smell and taste as well as gastrointestinal symptoms like diarrhoea were not uncommon; however, there was a report of a patient with seizure activity.[20] Reports that were more generalisable to the broader population found no increased risk of HIV virally suppressed individuals being hospitalised or suffering excess COVID-19 morbidity and mortality.[28-30, $33,40]$ Where there was increased risk of severe disease, patients had co-morbidities like hypertension, diabetes mellitus, obesity and chronic kidney disease.[31] Also, it was suggested that HIV-infected individuals ought to receive generally the same treatment for COVID-19 as the general populace.[14] At least four COVID-19 patients newly diagnosed

97 with HIV recovered.[9, 10, 12, 38] The protease inhibitor, darunavir, was found unlikely to prevent SARS-CoV-2 infection in HIV patients.[15] There have been reports of co-infected patients with solid organ transplants of the kidney and liver recovering.[23, 39] 
medRxiv preprint doi: https://doi.org/10.1101/2020.06.04.20122606; this version posted June 7, 2020. The copyright holder for this preprint (which was not certified by peer review) is the author/funder, who has granted medRxiv a license to display the preprint in perpetuity.

It is made available under a CC-BY 4.0 International license .

\section{Discussion}

102

103

104

105

106

107

108

This brief evidence map provides an up-to-date overview of the SARS-CoV-2/COVID-19 and HIV/AIDS co-infection literature. Its strengths include the use of explicit search criteria and the provision of a supplementary appendix providing key summaries of the studies on the topic. Although there was no search language restriction, only English language studies were retrieved, which raises the possibility of bias.

The finding that darunavir is likely to be ineffective at preventing COVID-19 in people living with HIV is in keeping with the finding that lopinavir-ritonavir did not provide benefit in the treatment of COVID-19.[41] This suggests that existing HIV therapy regimens should not be switched in patients with SARS-CoV-2 co-infection to protease inhibitor based medication.

It is interesting to note that reports emerged from countries in a similar temporal sequence in concert with how the COVID-19 pandemic epicentre moved from Asia, then to Europe and then to the Americas. The current global burden of COVID-19 approximates, to an extent, the amount of co-infection literature from the respective continents. To the best of our knowledge, there are no reported cases of co-infection from Oceania, which has the lowest number of COVID-19 cases. Africa which has a substantial burden of HIV/AIDS, but a relatively low COVID-19 burden has reports of two patients.[1, 34, 36]

The interaction with opportunistic infections like tuberculosis and pneumocystis jirovecii merits further consideration.[12] As therapies for COVID-19 emerge, drug interactions mandate exploration. Along with mental health aspects associated with co-infection. Pregnant women represent a special population.[42] As far as we know, no co-infection case has been reported during pregnancy. Because literature is expanding at pace, this synthesis is envisaged to be living and will be updated regularly and with more detail. Due to the rapidly 
medRxiv preprint doi: https://doi.org/10.1101/2020.06.04.20122606; this version posted June 7,2020 . The copyright holder for this preprint (which was not certified by peer review) is the author/funder, who has granted medRxiv a license to display the preprint in perpetuity.

It is made available under a CC-BY 4.0 International license .

124

125

126

127

128

129

130

131

132

133

134

135

136

137

138

139

140

141

142

143

144

expanding literature [4] such brief evidence synthesis pieces provide a platform for researchers, policy makers, clinicians and others to quickly discover and build relevant insights.

\section{Conclusion}

Based on studies that could be extrapolated to the general population, co-infected individuals with suppressed HIV viral loads did not have disproportionate COVID-19 morbidity and mortality. At least four patients, newly diagnosed with HIV survived COVID-19.

\section{Conflict of interest}

None declared

\section{Ethics}

Not required because publicly available data was used

\section{Funding}

None

\section{References}

1. Feldman, C., Potential impact of SARS-CoV-2 infection in HIV-positive patients in South Africa. Wits Journal of Clinical Medicine, 2020. 2(Special Issue 1): p. 19-24. 
medRxiv preprint doi: https://doi.org/10.1101/2020.06.04.20122606; this version posted June 7, 2020. The copyright holder for this preprint (which was not certified by peer review) is the author/funder, who has granted medRxiv a license to display the preprint in perpetuity.

2. Cainelli, F., et al., HIV and SARS-Coronavirus-2 Epidemics: Possible Interactions and Need for Studies, Especially in Africa. Frontiers in Medicine, 2020. 7: p. 216.

3. $\mathrm{Wu}, \mathrm{Z}$. and J.M. McGoogan, Characteristics of and Important Lessons From the Coronavirus Disease 2019 (COVID-19) Outbreak in China: Summary of a Report of 72314 Cases From the Chinese Center for Disease Control and Prevention. JAMA, 2020. 323(13): p. 1239-1242.

4. Brainard, J., Scientists are drowning in COVID-19 papers. Can new tools keep them afloat. 2020.

5. Zhu, F., et al., Co-infection of SARS-CoV-2 and HIV in a patient in Wuhan city, China. Journal of Medical Virology, 2020. 92(6): p. 529-530.

6. Guo, W., et al., A survey for COVID-19 among HIV/AIDS patients in two Districts of Wuhan, China. AIDS Patients in Two Districts of Wuhan, China (3/4/2020), 2020.

7. Zhao, J., et al., Early Virus Clearance and Delayed Antibody Response in a Case of Coronavirus Disease 2019 (COVID-19) With a History of Coinfection With Human Immunodeficiency Virus Type 1 and Hepatitis C Virus. Clinical Infectious Diseases, 2020.

8. Chen, J., et al., Computed Tomography Imaging of an HIV-infected Patient with Coronavirus Disease 2019 (COVID-19). Journal of Medical Virology, 2020. n/a(n/a).

9. Wang, M., et al., One case of coronavirus disease 2019 (COVID-19) in a patient coinfected by HIV with a low CD $4<$ sup $>+</$ sup $>T$-cell count. International Journal of Infectious Diseases, 2020. 96: p. 148-150.

10. Wu, Q., T. Chen, and H. Zhang, Recovery from COVID-19 in two patients with coexisted HIV infection. Journal of Medical Virology. n/a(n/a).

11. Chen, L., et al., Severe Acute Respiratory Syndrome Coronavirus 2 Infection in Patients Living with Human Immunodeficiency Virus: Case Reports and Review of the Literature.

12. Blanco, J.L., et al., COVID-19 in patients with HIV: clinical case series. The Lancet HIV, 2020. 7(5): p. e314-e316.

13. Casas Rojo, J.M., et al., Clinical characteristics of patients hospitalized with COVID19 in Spain: results from the SEMI-COVID-19 Network. medRxiv, 2020: p. 2020.05.24.20111971.

14. Vizcarra, P., et al., Description of COVID-19 in HIV-infected individuals: a singlecentre, prospective cohort. The Lancet HIV.

15. Riva, A., et al., Darunavir does not prevent SARS-CoV-2 infection in HIV patients. Pharmacological research, 2020. 157: p. 104826-104826.

16. Gervasoni, C., et al., Clinical features and outcomes of HIV patients with coronavirus disease 2019. Clinical Infectious Diseases, 2020.

17. Drain, P.K. and N. Garrett, SARS-CoV-2 pandemic expanding in sub-Saharan Africa: Considerations for COVID-19 in people living with HIV. EClinicalMedicine, 2020. 22.

18. Richardson, S., et al., Presenting Characteristics, Comorbidities, and Outcomes Among 5700 Patients Hospitalized With COVID-19 in the New York City Area. JAMA, 2020.

19. Karmen-Tuohy, S., et al., Outcomes among HIV-positive patients hospitalized with COVID-19. medRxiv, 2020: p. 2020.05.07.20094797.

20. Haddad, S., et al., Encephalopathy and seizure activity in a COVID-19 well controlled HIV patient. IDCases, 2020. 21: p. e00814.

21. Benkovic, S., M. Kim, and E. Sin, 4 Cases: HIV and SARS-CoV-2 Co-infection in patients from Long Island, New York. Journal of Medical Virology. n/a(n/a). 
medRxiv preprint doi: https://doi.org/10.1101/2020.06.04.20122606; this version posted June 7, 2020. The copyright holder for this preprint (which was not certified by peer review) is the author/funder, who has granted medRxiv a license to display the preprint in perpetuity.

22. Patel, R.H. and P.M. Pella, COVID-19 in a patient with HIV infection. Journal of Medical Virology, 2020. n/a(n/a).

23. Kumar, R.N., et al., COVID-19 in an HIV-positive Kidney Transplant Recipient. Transplant Infectious Disease, 2020. n/a(n/a): p. e13338.

24. Garibaldi, B.T., et al., Patient trajectories and risk factors for severe outcomes among persons hospitalized for COVID-19 in the Maryland/DC region. medRxiv, 2020: $\mathrm{p}$. 2020.05.24.20111864.

25. Suwanwongse, K. and N. Shabarek, Clinical features and outcome of HIV/SARS-CoV2 co-infected patients in the Bronx, New York City. Journal of Medical Virology, 2020. $\mathbf{n} / \mathbf{a}(\mathrm{n} / \mathrm{a})$.

26. Argenziano, M.G., et al., Characterization and clinical course of 1000 patients with coronavirus disease 2019 in New York: retrospective case series. BMJ, 2020. 369: p. m1996.

27. Ridgway, J.P., et al., A Case Series of Five People Living with HIV Hospitalized with COVID-19 in Chicago, Illinois. AIDS Patient Care STDS, 2020.

28. Shalev, N., et al., Clinical characteristics and outcomes in people living with HIV hospitalized for COVID-19. Clin Infect Dis, 2020.

29. Okoh, A.K., et al., COVID-19 pneumonia in patients with HIV - A Case Series. J Acquir Immune Defic Syndr, 2020.

30. Docherty, A.B., et al., Features of 20133 UK patients in hospital with covid-19 using the ISARIC WHO Clinical Characterisation Protocol: prospective observational cohort study. BMJ, 2020. 369: p. m1985.

31. Childs, K., et al., Hospitalized patients with COVID-19 and HIV: a case series. Clin Infect Dis, 2020.

32. Altuntas Aydin, O., H. Kumbasar Karaosmanoglu, and K. Kart Yasar, HIV/SARSCoV-2 co-infected patients in Istanbul, Turkey. Journal of Medical Virology. $\mathbf{n} / \mathbf{a}(\mathrm{n} / \mathbf{a})$.

33. Härter, G., et al., COVID-19 in people living with human immunodeficiency virus: a case series of 33 patients. Infection, 2020.

34. Parker, A., et al., HIV and SARS-CoV-2 co-infection: The diagnostic challenges of dual pandemics. SAMJ: South African Medical Journal, 2020. 110: p. 1-3.

35. Louisa, S.J., W.X. Lin Serene, and S. Gollamudi, A case of HIV and SARS-CoV-2 coinfection in Singapore. J Acquir Immune Defic Syndr, 2020.

36. Baluku, J.B., et al., HIV and SARS-CoV-2 co-infection: A case report from Uganda. Journal of Medical Virology. $\mathbf{n} / \mathbf{a}(\mathrm{n} / \mathrm{a})$.

37. Iordanou, S., et al., Severe SARS-CoV-2 pneumonia in a 58-year-old patient with HIV: a clinical case report from the Republic of Cyprus. Journal of Medical Virology, 2020. $\mathbf{n} / \mathbf{a}(\mathrm{n} / \mathbf{a})$.

38. Nakamoto, T., et al., A case of SARS-CoV-2 infection in an untreated HIV patient in Tokyo, Japan. Journal of Medical Virology, 2020. n/a(n/a).

39. Müller, H., et al., Recovery from COVID-19 following Hepatitis C, Human Immunodeficiency Virus Infection and Liver Transplantation. American Journal of Transplantation, 2020. $\mathbf{n} / \mathbf{a}(\mathrm{n} / \mathrm{a})$.

40. Miró, J.M., J. Ambrosioni, and J.L. Blanco, COVID-19 in patients with HIV \&\#x2013; Authors' reply. The Lancet HIV.

41. Cao, B., et al., A Trial of Lopinavir-Ritonavir in Adults Hospitalized with Severe Covid-19. N Engl J Med, 2020. 382(19): p. 1787-1799.

42. Shanes, E.D., et al., Placental Pathology in COVID-19. American Journal of Clinical Pathology, 2020. 